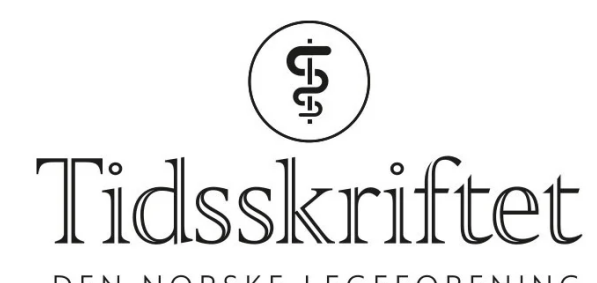

DEN NORSKE LEGEFORENING

\title{
Kolangiokarsinom behandlet med tumoragnostisk legemiddel
}

KORT KASUISTIKK

THURIDUR THORSTEINSDOTTIR

tuthor@vestreviken.no

Onkologisk seksjon

Drammen sykehus

Vestre Viken

Thuridur Thorsteinsdottir er lege i spesialisering.

Forfatteren har fylt ut ICMJE-skjemaet og oppgir ingen interessekonflikter.

\section{ODD TERJE BRUSTUGUN}

Onkolog dr.med., Kreftseksjonen

Drammen sykehus

Vestre Viken

Tumoragnostiske legemidler er legemidler rettet mot molekylære forandringer i kreftceller uavhengig av tumors histologiske diagnose. Vi beskriver en kvinne i zo-årene med kolangiokarsinom med en forandring i genet for onkoproteinet tropomyosinreseptorkinase. Som en av de første som behandles med et tumoragnostisk legemiddel i Norge, viser hun nå fremgang under behandling med en tropomyosinreseptorkinasehemmer.

En tidligere frisk lite-røykende kvinne i zo-årene oppsøkte lege fordi hun følte seg sliten og hadde smerter i øvre del av buken. Hun ble utredet med blant annet CT abdomen, som viste multiple metastasesuspekte lesjoner opptil $12 \mathrm{~cm}$ i diameter i lever og forstørrede lymfeknuter i abdomen (figur 1a). Biopsi fra lever viste adenokarsinom. MR lever sannsynliggjorde diagnosen kolangiokarsinom med affeksjon av nesten alle leversegmenter. 

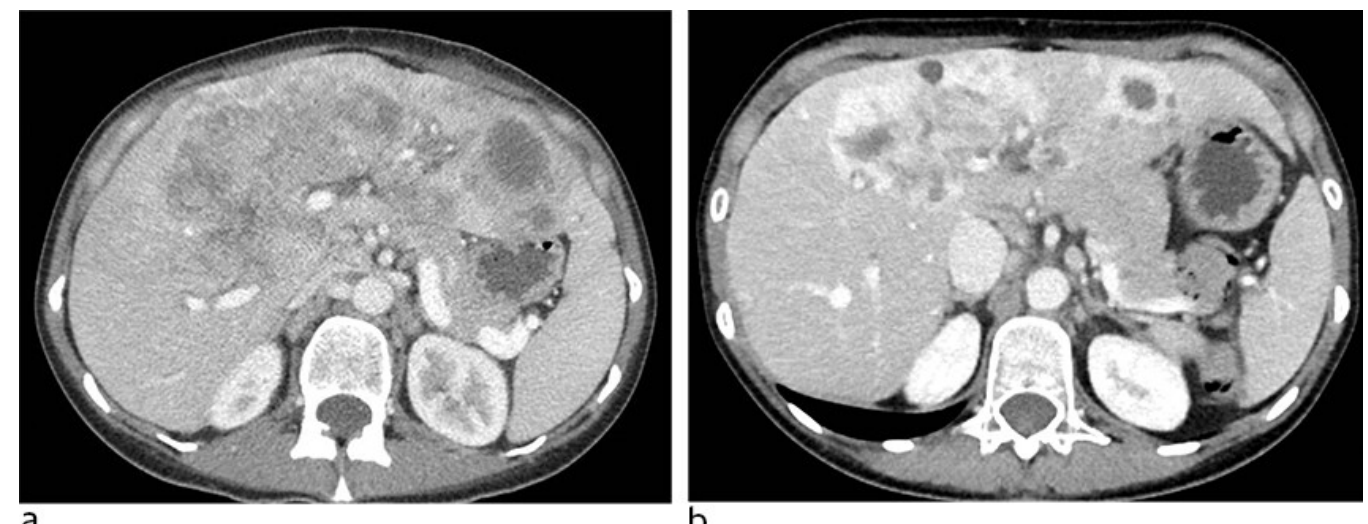

Figur 1 CT før (a) og fem uker etter oppstart (b) av behandling.

Det ble startet standard palliativ kjemoterapi med gemcitabin og cisplatin. Med tanke på mulig inklusjon i klinisk studie ble tumorvev analysert med nestegenerasjonssekvensering (NGS, Illumina Childhood Cancer Panel, Illumina, Hayward, USA), der det ble påvist en spesifikk genforandring, fusjonstranskriptet RNA-bindende protein med multippel spleising-nevrotrof reseptortyrosinkinase-3 (RBPMS-NTRK3).

Etter to måneder med cellegift ble det påvist progrediering i form av stigende tumormarkører, større lymfeknuter og $ø$ kende ascites samt $\varnothing$ kende trøtthet og magesmerter. For kolangiokarsinom finnes ingen aktuell andrelinjebehandling, og det fantes ingen relevante kliniske studier å støtte seg på. Legemidler rettet mot tropomyosinreseptorkinase, såkalte TRK-hemmere, er foreløpig ikke vurdert av Beslutningsforum, men behandling kan unntaksvis innvilges av helseforetakets fagdirektør (1). På grunn av den påviste NTRK-fusjonen var det allerede før progredieringen søkt om behandling med TRK-hemmer under unntaksordning. Dette ble innvilget med medikamentet entrektinib, begrunnet med lav alder og stor sannsynlighet for effekt.

Pasienten kunne dermed raskt starte målrettet behandling. Entrektinibkapsler ble gitt i standard dose, 6oo mg én gang daglig, og allerede etter fem dager rapporterte hun om bedret form, mindre mageproblemer og økt matlyst. Tumormarkøren CA125 (normalverdi $<35 \mathrm{kU} / \mathrm{L}$ ) var på $45 \mathrm{kU} / \mathrm{L}$ ved oppstart av kjemoterapi og hadde $ø \mathrm{kt}$ til $685 \mathrm{kU} / \mathrm{L}$ ved progrediering. Etter én uke med entrektinib falt den, og innen innen tre uker var normale verdier nådd (figur 2).

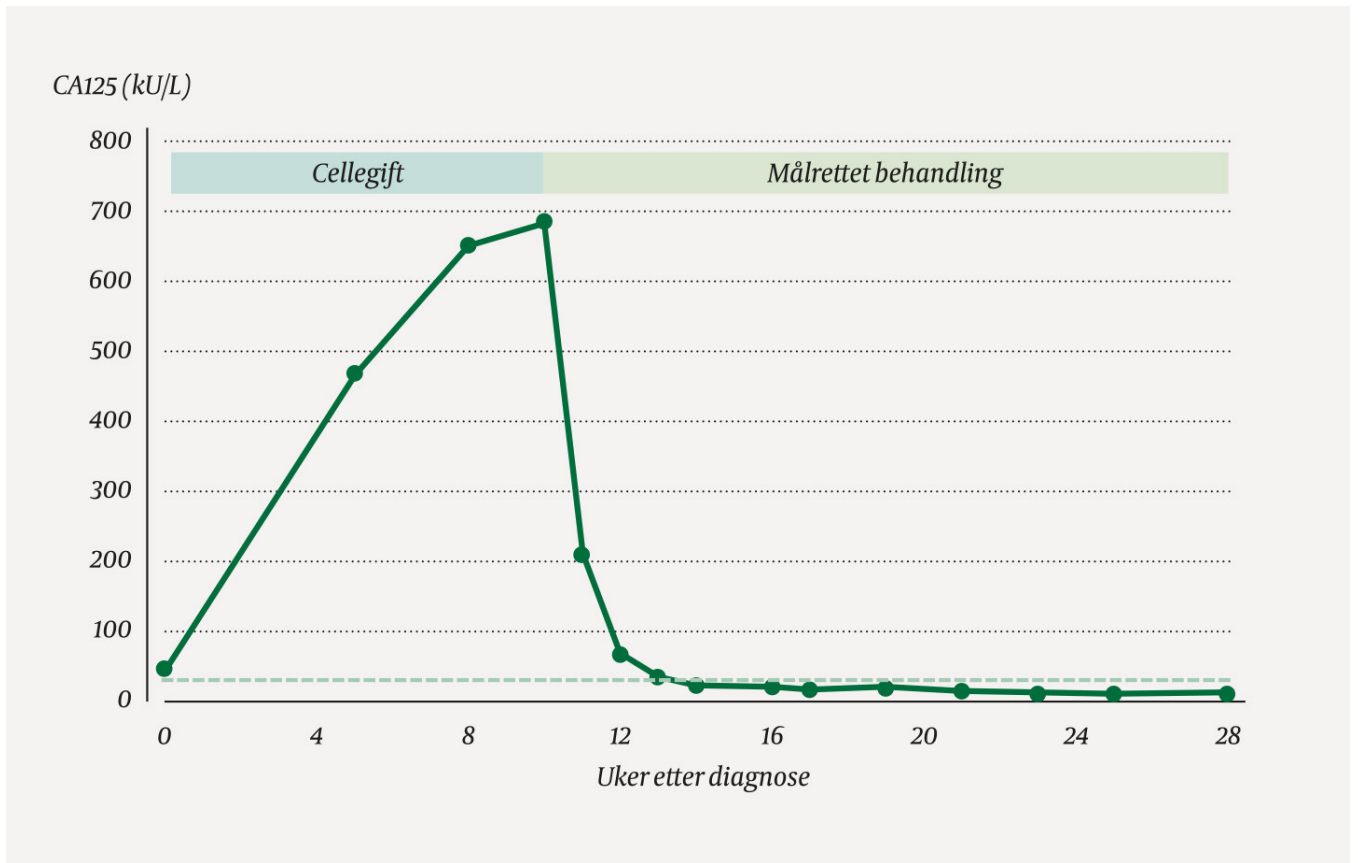

Figur 2 Forløp av tumormarkøren CA125. Stiplet linje indikerer øvre normalområde. 
CT-bilder tatt etter fem ukers behandling med entrektinib viste tydelig respons. Store konfluerende tumormasser sentralt i leveren var minket til 9,8 cm fra 11,7 cm før start av entrektinib, og en metastase i venstre leverlapp hadde blitt redusert fra 7,2 cm til 4,9 cm (figur 1b). Det var også tilbakegang av ascites.

Hun tolererte behandlingen relativt godt, men noen bivirkninger oppsto i form av trykkfølelse i bryst og lett forhøyet troponin I, urinretensjon, mild dysestesi, forstoppelse og dysgeusi.

På grunn av bivirkningene ble dosen etter seks uker redusert til $400 \mathrm{mg}$ én gang daglig. Det ble utført koronarangiografi og ekkokardiografi, med normale funn. Etter kort tid med redusert dose ble troponinverdien normalisert, og trykkfølelsen i brystet forsvant. Urinretensjonen ble behandlet med mirabegron 50 mg én gang daglig, med god effekt.

Pasienten har undergått behandling i fem måneder og har nå god toleranse. Behandlingen vil fortsette så lenge kreftsykdommen er stabil, og hun vil bli fulgt opp med regelmessige kontroller.

\section{Diskusjon}

Genrearrangering som involverer nevrotrofkinasegener (NTRK1, NTRK2, NTRK3), er sjeldne, men kan forekomme med varierende hyppighet ved de fleste kreftformer, både hos voksne og barn, og er tidligere omtalt i Tidsskriftet (므). Ved noen sjeldne kreftvarianter påvises NTRK-fusjoner hyppig. Ved sekretorisk brystkreft, som utgjør ca. o,15\% av all brystkreft, finnes slik genforandring hos over $90 \%$. Mens ved den vanlige ikke-sekretoriske brystkrefttypen påvises NTRK-fusjoner kun hos o,o8\% (3).

Genrearrangeringen kan forårsake uttrykk av konstitutivt aktive fusjonsproteiner med tropomyosinreseptorkinase (TRKA/B/C), som er onkogene drivere av tumorvekst. Det er utviklet flere småmolekylære TRK-hemmere, deriblant entrektinib og larotrektinib, som begge er godkjent til bruk av det europeiske legemiddelbyrået $\operatorname{EMA}(4,5)$.

Både larotrektinib og entrektinib er tyrosinkinasehemmere med effekt på TRKA/B/Cproteinet. Entrektinib har i tillegg effekt ved c-ros onkogen 1 (ROS1)- og anaplastisk lymfomkinase (ALK)-mutasjoner. Entrektinib, som ble valgt her, har indikasjon som monoterapi hos pasienter med solide tumorer med påvist NTRK-genfusjon, og der det ikke er tilfredsstillende behandlingsalternativer. Tid til progresjon er vist å variere betydelig, men median responsvarighet med entrektinib er rapportert å være ti måneder, men med vide konfidensintervall (5). TRK-hemmere gir betydelig mindre bivirkninger enn cellegift, men vektøkning og anemi er de hyppigst rapporterte bivirkningene ved entrektinib.

Det er begrenset med data på forekomst av NTRK-fusjon ved kolangiokarsinom. I en studie var forekomsten $0,36 \%(\underline{6}, 7$.$) . Testing av kreftpasienter for sjeldne genforandringer som$ NTRK-fusjon betinger bruk av nestegenerasjonssekvensering. Slike analyser blir ikke rutinemessig utført ved all kreft i Norge, men hos pasienter med få behandlingstilbud, og kanskje spesielt hos yngre pasienter, bør slik testing vurderes. Flere sykehus i Norge har nå nestegenerasjonssekvensering som del av sin patologidiagnostikk, og innføring av denne metoden blir stimulert av politisk ledelse for å sikre persontilpasset behandling ( $\underline{8})$. Kostnader ved utvidet testing bør nok også vurderes opp mot sannsynligheten for betydningsfulle funn.

Så vidt vi har fått opplyst fra medikamentprodusentene, er vår pasient den første NTRKpositive kreftpasienten som mottar tumoragnostisk kreftbehandling i Norge. Kliniske studier har vist at slik behandling kan ha langvarig effekt hos pasienter med mutasjonen, uavhengig av tumorgruppe (4,5). Alle som får målrettet kreftbehandling, vil før eller siden utvikle resistens. Det vil da være relevant å utføre molekylære analyser av rebiopsi for å 
finne årsaksmekanismen, som kan legges til grunn ved valg av ny behandling (9.). Det foregår kliniske studier med nye TRK-hemmere som kan være effektive når resistens oppstår. Dessverre er det ingen slike studier tilgjengelige i Norge nå.

Vår pasient hadde svært rask respons og god toleranse for behandlingen, og det er å håpe at hun får langvarig nytte. Dette eksemplet viser betydningen av nestegenerasjonssekvensering av kreftsvulster og tilgang til tumoragnostisk kreftbehandling.

Pasienten har gitt samtykke til at artikkelen blir publisert. Vi takker Avdeling for bildediagnostikk, Avdeling for laboratoriemedisin og Avdeling for klinisk patologi ved Vestre Viken samt Seksjon for molekylcerpatologi, Avdeling for patologi ved Oslo universitetssykehus for godt samarbeid. Artikkelen erfagfellevurdert.

\section{LITTERATUR}

1. Nye Metoder. Unntaksordning. https://nyemetoder.no/om-systemet/unntaksordning Lest 22.1.2021.

2. Børset M. Tumoragnostiske legemidler og framtidig kreftbehandling. Tidsskr Nor Legeforen 2019; 139. doi: 10.4045/tidsskr.19.0005. [PubMed][CrossRef]

3. Pestana RC, Sen S, Hobbs BP et al. Histology-agnostic drug development - considering issues beyond the tissue. Nat Rev Clin Oncol 2020; 17: 555-68. [PubMed][CrossRef]

4. Hong DS, DuBois SG, Kummar S et al. Larotrectinib in patients with TRK fusion-positive solid tumours: a pooled analysis of three phase 1/2 clinical trials. Lancet Oncol 2020; 21: 531-40. [PubMed] [CrossRef]

5. Doebele RC, Drilon A, Paz-Ares L et al. Entrectinib in patients with advanced or metastatic NTRK fusion-positive solid tumours: integrated analysis of three phase 1-2 trials. Lancet Oncol 2020; 21: 27182. [PubMed][CrossRef]

6. Drilon A. TRK inhibitors in TRK fusion-positive cancers. Ann Oncol 2019;30: viii23-, i3o. [CrossRef]

7. Rosen EY, Goldman DA, Hechtman JF et al. TRK fusions are enriched in cancers with uncommon histologies and the absence of canonical driver mutations. Clin Cancer Res 2020; 26: 1624-32. [PubMed][CrossRef]

8. Regjeringen.no. Sykehustalen 2021. https://www.regjeringen.no/no/aktuelt/sykehustalen2021/id2827149/ Lest 22.1.2021.

9. Rohrberg KS, Lassen U. Detecting and targeting NTRK fusions in cancer in the era of tumor agnostic oncology. Drugs 2021; 81: 445-52. [PubMed][CrossRef]

Publisert:31. august 2021. Tidsskr Nor Legeforen. DOI: 10.4045/tidsskr.21.0064

Mottatt 22.1.2021, første revisjon innsendt 25.3.2021, godkjent 26.4.2021.

Publisert under åpen tilgang CC BY-ND. Lastet ned fra tidsskriftet.no 26. april 2023. 